\title{
Research on Construction of Employment Guidance System in Higher Vocational Colleges under the New Normal
}

\author{
Fei LIAN \\ Nanjing Vocational Institute of Technology \\ Nanjing, China \\ e-mail: 2439127660@qq.com
}

\begin{abstract}
Under the new normal, higher vocational colleges will be confronted with severer employment reality. It is an imperative problem for higher vocational colleges to do employment guidance work of graduates in higher vocational colleges under the new normal. This paper analyzes the impacts of new normal on employment guidance work in higher vocational colleges and elaborates the necessity of employment guidance system in higher vocational colleges under the new normal. It teases the construction idea of employment guidance system in higher vocational colleges under the new normal, and proposes construction paths.
\end{abstract}

Keywords-new normal; higher vocational colleges; employment guidance system

\section{INTRODUCTION}

Currently, the employment rate in higher vocational colleges increases by years. However, affected by social ideas, education levels, knowledge structure, personal quality and multiple factors, employment level is still not high and employment quality is still not strong. Employment vigor is also short of vivid embodiments. In comparison with the demands of economy new normal for talents' development, there are still large gaps. Higher vocational colleges must creatively adopt the idea and thought of "new normal", further updating service concept and perfecting training mode. Education quality and connotation should be improved; the guidance and service system of employment and entrepreneurship should be constructed and optimized constantly.

II. ANALYSIS OF IMPACTS OF NEW NORMAL ON EMPLOYMENT GUIDANCE WORK IN HighER VOCATIONAL COLleGES

\section{A. Connotation of New Normal and Its New Requirements for Higher Vocational Education}

"New normal" includes the three features, namely, speed increase and gear shift, structure upgrading, and innovation drive. The main manifestations are as follows: firstly, China's social economy shifts from high-speed growth to mediumhigh speed growth. Secondly, social industrial structure transforms from quantitative enlargement to qualitative leap; meanwhile, consumption becomes the main body of demand growth. Thirdly, technological progress and innovation in dynamic structure become the "major causes" which determine success or failure. Socioeconomic development under new normal puts forward higher requirements for talents' skills and qualities. Higher vocational education, as one of the important ways of acquiring vocational knowledge and enhancing employability, must conform to the economic development trend and construct higher vocational education and employment mode which correspond to the objective reality, so that it has positive impacts on the economic development of the new normal.

\section{B. Current Situation of Employment Guidance in Higher Vocational Colleges under the New Normal}

In recent years, China and Chinese government has paid high attention to employment guidance work of higher vocational college graduates; a series of employment guidance policies have been introduced. Higher vocational colleges have also developed specific management systems and set up full-time employment guidance institutions. During the teaching process, they have also combined their specialized characteristics as well as employment situation of graduates, and set up courses relevant to employment. Most high vocational colleges establish special employment websites, transmitting employment policies and employment information for graduates promptly and effectively. Some higher vocational colleges have also carried out follow-up survey work of graduates; they have organized follow-up survey work of employment intension of graduates, employment status and employing unit satisfaction degree.

\section{Existing Problems in Employment Guidance Work under the New Normal}

Although higher vocational colleges have paid great efforts in employment guidance work, there are still many problems at present under the new normal.

1) Employment guidance is short of whole process: Currently, the employment guidance in many higher vocational colleges mainly focuses on holding employment situation report meetings and lectures to carry out employability skill guidance, before graduates are leaving colleges soon. Employment positions are only provided through on-campus job fairs and employment information before graduation. This kind of surprise career guidance lacks whole process of consideration, which can only solve temporarily-encountered problems in job interviews of college students. The employment quality and 
competitiveness of graduates in higher vocational colleges depend on employability. Employability can not be achieved through short-term employment guidance. Instead, students should prepensely cultivate employability at the very beginning of their enrolments. Students should identify their own vocational tendency through professional tests; they should set career development goals and career planning; they should also acquire skills through learning and practicing. The process requires full involvement of employment guidance; individualized guidance should be provided in accordance with students' features, in order to make every student obtain better development.

2) Employment guidance is equipped with strong theoretical property, lacking maneuverability: A considerable part of employment guidance work in higher vocational colleges is still conducted in course teaching model, which is similar to theoretical teaching of other cultural courses. Students in higher vocational colleges can only choose to receive passively and have rigid understandings in the face of the theoretical knowledge. They can not effectively apply the theoretical knowledge to employment practice. Many students just learn the knowledge emblematically in order to deal with exams, seriously affecting the normal performance of employment guidance work value in higher vocational colleges.

3) High-quality employment guidance staffs are in want: At the moment, most people who work on employment guidance work are counselors or head teachers, and most of them hold "several posts" simultaneously. Most employment guidance teachers in higher vocational colleges start to engage in this work after graduating from colleges, lacking employment guidance knowledge and practical experience. Although they can still undertake training and learning, they have superabundant theories and insufficient practice. It is difficult to meet the requirements of "professionalization, expertization and occupationization".

4) Cooperation between departments, between departments and mass organizations is insufficient: Through investigation, it can be found that maldistribution phenomenon of employment guidance resources between colleges and departments is ubiquitous in all higher vocational colleges. Some departments are equipped with abundant resources, while the others have scarce resources. The departments with abundant resources have plenty of activities, while the departments with scarce resources have insufficient activities. The contradiction can be addressed through cooperation between departments. However, in reality, corresponding cooperation and resource sharing are in want between different departments. In this connection, the contradiction between employment guidance work of "having nothing to do" in most departments and employment guidance work of "having so many to do" in few departments becomes increasingly obvious. Likewise, employment guidance resource sharing and cooperation between mass organizations, between departments and mass organizations are also scanty, causing the fact that employment guidance resource imbalance phenomenon becomes severer.

\section{NECESSITIES OF CONSTRUCTING EMPLOYMENT GuIDANCE SySTEM IN Higher VocATIONAL COLLEGES UNDER THE NEW NORMAL}

\section{A. Requirement for Ensuring National and Social Stable Development}

Under the new normal, the employment rate and quality are confronted with unprecedented impacts. Therefore, the establishment of personnel training mode in higher vocational colleges based on various types of collegeenterprise cooperation promotes the characterized development of students in higher vocational colleges. Exploring scientific student vocation guidance and service system attains the organic unification of sustainable development of students' vocation and career, avoiding the short-sighted behavior of unilaterally pursuing employment rate and ignoring employment quality. In this connection, graduates in higher vocational colleges can have positions of applying what they have learned, so that they can live and work in peace and contentment and be in their proper places, eliminating restlessness and creating atmosphere and conditions for the harmony of the whole society. That is how to effectively promote the construction of a harmonious society.

\section{B. Requirement for Deepening Higher Vocational Education Reform}

Persisting in "taking service as tenet and employment as orientation, promoting education and teaching reform" is the intrinsic requirement of higher vocational education reform. Employment is regarded as the measurement index of college running, guiding colleges to carry out talent training work. Serving socioeconomic transformation and upgrading in regions is taken as the tenet; the pillar industry, strategic industry and emerging industry of regional economy are taken as the objects; the cultivations of qualified high-skilled talents with enterprise production management as well as science and technology service are taken as the objectives. The specialized curriculum system which centers on production practicalness should be constructed and personnel training mode in higher vocational colleges should be innovated, according to the requirements of enterprise positions and post clusters. Only by constantly deepening educational reforms and building characteristics, can higher vocational colleges cultivate high-skilled talents that the society needs, so as to win the recognitions of the enterprise industry.

\section{Requirement for College Students to Realize Value of Life}

Along with the continuous transformation and upgrading of economic structure as well as constant deep changes of social structure, college students generate independent and 
various changes in terms of view of life values, lacking planning and thinking of career life after graduation. In this connection, in the study career of college students on campus, teachers should guide students to plan career throughout the whole journey and guide students to establish correct occupation choice mindset. College students should correctly analyze individual positions in the social market and enhance sense of social responsibility, so that they can realize selfworth. At the same time, they can also make contributions to the country and society. That is how to break one-step and single-minded employment attitude, taking the road of fitting into society and achieving personal sustainable development.

IV. CONSTRUCTION IDEA OF EMPLOYMENT GUIDANCE SYSTEM IN Higher Vocational COLLEGES UNDER THE NEW NORMAL

\section{A. Employment Guidance System Must Be Specialized}

Specialization indicates not only the professionalization of teaching content, guidance methods and means, but also the professionalization of teaching staffs and subsequent follow-up service, embodying employment guidance level of higher vocational colleges. It is conducive to improve the efficiency and quality of employment guidance work.

\section{B. Employment Guidance System Must Be Whole- processed}

Whole process signifies the period from the time when students in higher vocational colleges enter colleges to the time after students obtain employment. The whole process runs through the whole study course of students. The wholeprocess follow-up guidance and information feedback should be carried out for students; student employment data system should be built up, laying data foundations for future employment guidance work.

\section{Employment Guidance System Must Be Personalized}

Personalization indicates that scientific employment guidance education ways and methods should be formulated in view of students of different disciplines with different employment goals, especially for the differentiated demands of special employment groups. Students should be induced to formulate employment and job searching plans which conform to their own requirements. Students should be supervised and urged to implement these plans. Measures should be adjusted to local conditions, guaranteeing the pertinence and practicability of employment guidance work.

\section{Employment Guidance System Must Be Practical}

Practicality means that students can hone themselves in employment practice through various forms of employment platforms, so that they can deepen their understandings of the learned employment policies, procedures, interviewing techniques and self-employment.

\section{CONSTRUCTION OF EMPLOYMENT GUIDANCE SySTEM in Higher Vocational COLLEGES UNDER THE NEW NORMAL}

\section{A. Constructing Employment Guidance Curriculum System with Diverse Contents and Strong Maneuverability}

Career planning courses and employment guidance theory courses should be set up during the freshman year, so that students can have reasonable planning of four-year college life and they can earnestly abide by and carry out the plans at the very beginning of their entrances. In the second year after their entrances, professional learning should be carried out, so that students can acquire favorite or interested professional knowledge and skills. Moreover, they can be also combined with the future employment orientations of students. Excellent graduates in colleges should be invited to give talks, sharing their successful experiences and lessons with students. Meanwhile, they can combine their thoughts and feelings to analyze and discuss the future demand direction of talents in enterprises. Students should be encouraged to master relevant skills or obtain relevant certificates. This can enable students to have preliminary ideological understandings comprehensions of future employment, which is conducive to their future employments. Some case studies or workplace simulations should be regularly conducted, so that students can mental preparations for employment and master employability skills.

\section{B. Constructing Employment Guidance System of College- enterprise Interaction}

The construction of employment guidance service work network is a long-term accumulation process. College employment guidance service institutions can fully use platforms and play leading roles to proactively carry out employment guidance work and do employment recommendation work of college students well, knowing about the demands for talents in enterprises and society. More employment forums and employment guidance lecture activities should be held, so that students can have sufficient understandings of employment. Career planning competitions and entrepreneurship design competitions should be organized, so that students can give full play to imagination and creativity, planning employment well. The working enthusiasm of these counselors should be constantly improved and the training for their employment guidance work should be strengthened, putting employment work into practice and making t employment guidance work achieve the desired results. In the process of deepening integration of production and education, college-enterprise cooperation and promoting combination of learning with working and the unity of knowing and doing, higher vocational colleges should also work together with enterprises and experts, center on employment guidance goals, and combine enterprise culture and job occupation requirements. In doing so, the improvement of vocational skills and the cultivation of professional spirits can be highly integrated; employment guidance education in colleges can be effectively extended to 
the internship period and work period outside campus. While they provide powerful helps for successful high-quality employments of students, they also offer opportunities of cultivation and choice for enterprises to recruit and select talents.

\section{Constructing Specialized and Professional Teaching Staffs of Employment Guidance}

The teaching staff structure of employment guidance should be optimally allocated; great efforts should be made to construct employment guidance team which combine the old, the middle-aged and the young and center on the middle-aged and the young. In the second place, specialization degree of employment guidance teachers should be improved. Measures should be formulated to attract excellent talents to participate in the employment guidance team. Teacher resources should be reasonably allocated. Teachers who know educational psychology, human resources management, sociology and other professional knowledge should be enriched into the employment guidance team. Trainings should be regularly organized, promoting professional visions and capabilities of employment guidance teachers. Appraisal management system of employment guidance teachers should be perfected; position responsibilities should be clarified and title promotion mechanisms should be perfected; personal interests of employment guidance teachers should be guaranteed.

\section{Constructing Impeccable Employment Guidance Follow-up and Feedback System of Graduates}

The employment guidance work in China's colleges and universities makes slow progress in terms of follow-up and feedback of students' employment, paying less attention to the employment rate and quality of students. Only when some colleges make evaluations, can they conduct relevant surveys. Necessary investigation means and methods are in want during the period of surveying. The results are not convincing. Colleges and universities should not only set up employment networks, but also conduct employment investigation networks. By doing so, they can timely gather and update employment status and development trend of graduates, demands for talents in employing units, and evaluations of students and other data. At the same time, they should also count and analyze the data, providing important references for major setups and skill trainings.

\section{E. Constructing Student Entrepreneurship Incubation System from Education to Support}

Innovation and entrepreneurship education is to foster career consciousness and ideas of students in higher vocational students and improve their entrepreneurial skills and capabilities, which can help some students in higher vocational colleges to achieve self employment and increase employment. Guidance curricula of innovation and entrepreneurship education should be offered, providing students with various kinds of platforms to carry out entrepreneurial practice. Conditional colleges can establish entrepreneurship incubation bases on campus, supporting students to conduct innovation and entrepreneurship incubation.

\section{CONCLUSION}

Employment work of students in higher vocational colleges is closely concerned with the development of national economy, happiness of many families as well as the existence and development of many higher vocational colleges. It is one of the significant focuses of the whole society. A scientific and reasonable employment guidance system is the shortcut to improve the employment rate and quality. Only by breaking traditional educational patterns and constructing the employment guidance system from which students and the society can gain benefit, the effectiveness, pertinence and enlightenment of employment guidance can be given full play to, enhancing students' capabilities to adapt to society and exist in the society.

\section{REFERENCES}

[1] Li Cunjin. Practical Approaches and Mechanisms of Cultivating Creative thinking Abilities of University Students. Innovation and Entrepreneurship Education, 2013 (1).

[2] Xie Kaiming. Employment Difficulties and Opportunities of College Graduates in the New Normal Economy Situation. Shandong Youth, 2014 (12).

[3] Yuan Xiaoxia. Current Problems of University Students' Employment and Countermeasures . Education and Vocation, 2016 (4).

[4] Zhang Jianjun, Yuan Xiuli. Research on Existing Problems and Improvement Countermeasures of Entrepreneurship Education in Higher Vocational Colleges[J].Guide to Business, 2016(6).

[5] Jiang Dongmei. Study on Current Situation and Countermeasures of Employment Guidance Education for Students in Higher Vocational Colleges[J].China Training, 2016(4). 